\title{
SELECTIVE REMOVAL OF TOXIC METALS FROM WASTE WATER USING p- CRESOL, DITHIOOXAMIDE AND FORMALDEHYDE (p-CDF)
}

\author{
S. S. Katkamwar , S. B. Kapoor and P. M. Telkhade \\ Arts, Commerce and Science College Tukum Chandrapur M.S. India \\ Corresponding author Email : Kapoor.sushil2012@gmail.com
}

\begin{abstract}
:
Terpolymer resins ( $\mathrm{p}-\mathrm{CDF}$ ) were synthesized by the condensation of $\mathrm{p}$-Cresol (p-C) and dithiooxamide (D) with formaldehyde $(\mathrm{F})$ in the presence of acid catalyst and using varied molar ratios of reacting monomers. Terpolymer resins compositions have been determined on the basis of their elemental analysis and the number average molecular weights of these resins were determined by conductometric titration in non-aqueous medium. Viscometric measurements in dimethyl formamide (DMF) have been carried out with a view to ascertain the characteristic functions and constants. The UV-visible, IR and proton nuclear magnetic resonance $(\mathrm{H}+\mathrm{NMR})$ spectra were studied to elucidate the structure. In present study, a batch equilibrium method was employed in the study of the selectivity of metal ions uptake, involved the measurement of the distribution of a given metal ions between the polymer sample and a solution contain metals ions. The copolymer resin $\mathrm{p}-\mathrm{CDF}$ has been synthesized by the condensation of p-Cresol, Dithiooxamide with formaldehyde in 1:1:2 molar ratio in presence of $2 \mathrm{M}$ Hydrochloric acid as catalyst. The newly synthesized copolymer resin has been characterized by UV- visible, IR and proton NMR spectral studies. Copolymer p-Cresol proved to be a selective chelating ion exchange polymer for certain metals. chelating ion exchange properties of this polymer where studied for $\mathrm{Fe} 3+, \mathrm{Cu} 2+\mathrm{Ni} 2+, \mathrm{Co} 2+, \mathrm{Zn} 2+, \mathrm{CD} 2+$, and $\mathrm{Pb} 2+$ ions.
\end{abstract}

\section{Keywords:}

Toxic Metals, Ion- exchanger, Metal ion uptake, Chelating resin.

\section{Introduction:}

Tercopolymer are macromolecular entities which form an integral part of the backbone. Tercopolymers are found to be amorphous powder or crystalline resinous in nature and form special class of polymers which are widely known for their uses. Condensation of phenol or hydrobenzoic acid with formaldehyde in presence of acid afforded a polymer, while condensation of hydrobenzoic acid and biuret with formaldehyde or trioxane in presence of acid as catalyst yields 
a Tercopolymer. This tercopolymers in general are found to be insoluble in most of the common organic solvent and are fuseable to clear melts. These Tercopolymer have better thermal stability and electrical properties than those of phenol - formaldehyde type copolymers. The tercopolymers can be used as ion-exchangers, semi-conductors, antioxidants, hardening agents, molding materials, rectifiers, dyes, fungicides in plants and living tissues. The heavy metal ion toxicity has increased substantially because of the use of metal ions as catalyst in various industries. Many methods have been developed for the pre-concentration and removal of metal ions such as electrodeposition, coprecipitation, and solid-liquid extraction. However, the metal ion removal by chelating ion-exchange resin using batch equilibration method has gained rapid acceptance because of its wide variety of sorbent phases, high degree of selectivity, high loading capacity and enhanced hydrophilicity [6]. Ionexchangers are widely used for the treatment of radioactive wastes from nuclear power stations [4]. Terpolymer is found very useful application as adhesive, high temperature flame resistant, fibers, coating materials, semiconductors, catalysis and ion exchange resins.[3,10,14] Ion-exchange resins have attracted much interest in the recent years due to their application in waste water treatment, metal recovery and for the identification of specific metal ions.[1,5]. The purpose of present study, is to explore the adsorption behavior of eight metal ions $\mathrm{Fe} 2+, \mathrm{Cu} 2+, \mathrm{Ni} 2+, \mathrm{Co} 2+, \mathrm{Zn} 2+, \mathrm{Cd} 2+$, and $\mathrm{Pb} 2+$ on the newly synthesized terpolymer resins $\mathrm{p}$-Cresol at different $\mathrm{pH}$ values, different concentrations of different electrolytes and at different shaking time intervals. The adsorption behavior of these metal ions are based on the affinity differences towards the chelating resins as functions of $\mathrm{pH}$, electrolyte concentrations and shaking time. The terpolymer resins under investigations are found to be cation exchanger having both ion-exchange group and chelating group in the same polymer matrix and the resin can be used selectively for the purpose of purification of waste water. One of the important application of chelating and functional polymers is their capability to recover 
metal ions from waste solution. Hence, the chelating ion exchange property of the $\mathrm{p}-\mathrm{CDF}$ terpotymer resin was also reported for specific metal ions. Pollution by toxic heavy metals due to their toxicities in relatively low concentration and tendency to bioaccumulation in the ecosystem, agriculture, and human body has received wide spread attention in recent years. Various approaches such as ion-exchange, reverse osmosis, electro dialysis, precipitation and adsorption techniques have been developed for the removal and recovery of the metal ions from sewage and industrial wastewater. Among these techniques, many research works have focused on metal ions removal by adsorption on chelating polymers, because they are reusable, easily separable, and with higher adsorption capacity and selectivity having physical and chemical stabilities $[2$, 7].

\section{Material and Method:}

Synthesis of p-Cresol (p-C) -Dithiooxamide (D)-Formaldehyde (F) Terpolymer Resins. The four different $\mathrm{p}-\mathrm{CDF}$ terpolymer resins have been successfully synthesized and abbreviated as shown in Table 1 . A mixture of p-Cresol $(1.08 \mathrm{~g}$, $0.1 \mathrm{~mol})$, and ditthiooxamide $(1.20 \mathrm{~g}, 0.1 \mathrm{~mol})$ and formaldehyde $(7.50 \mathrm{ml}, 0.2$ mol) in molar ratio of $1: 1: 2$ in the presence of $2 \mathrm{M}(200 \mathrm{ml}) \mathrm{HCl}$ as a catalyst has been prepared in round bottom flask. The resultant mixture was refluxed over an oil bath for heating at $120^{\circ} \mathrm{C} \pm 2^{\circ} \mathrm{C}$ for $5 \mathrm{hrs}$ with occasional shaking to ensure thorough mixing. The temperature of oil bath was controlled electrically with the help of dimmerstat. The resinous sticky green solid mass obtained was immediately removed from the flask as soon as the reaction period was over and then purified. Excellent yield of terpolymer resin can be obtained by this method. The reaction is shown as below in Fig.1. Some commercially available ion exchange resins are given in Table 1. 


\section{Result and Discussion:}

Ion-exchange properties p-Cresol - Dithiooxamide -Formaldehyde ( $\mathrm{p}$-CDF) Terpolymer Resins The results of the batch equilibrium study carried out with the terpolymer $\mathrm{p}-\mathrm{CDF}$ are presented. The ion-exchange study was carried out using three experimental variables of (a) ionic strength, (b) rate of metal uptake at different time intervals and (c) $\mathrm{pH}$ of aqueous medium. Among these three variables, two were kept constants and only one was varied at a time to evaluate its effect on metal uptake capacity of the polymers. I. Effect of electrolytes and their concentrations on metal ion uptake capacity We examined the influence of $\mathrm{ClO}_{-}-, \mathrm{NO}_{-}, \mathrm{Cl}-$ and $\mathrm{SO} 42-$ at various concentrations on the equilibrium of metal resin interaction. The data shows that the amount of metal ion taken up by a given amount of terpolymers depends on the nature and concentration of the electrolyte present in the solution. In the presence of perchlorate, chloride and nitrate ions the uptake of $\mathrm{Fe}(\mathrm{III}), \mathrm{Cu}$ (II) and $\mathrm{Ni}$ (II) ions increase with increasing concentration of the electrolytes, whereas in the presence of sulphate ions the amount of the above mentioned ions taken up by the terpolymer decrease with increasing concentration of the electrolyte. Moreover, the uptake of Co (II), $\mathrm{Zn}$ (II), Cd (II) and $\mathrm{Pb}$ (II) ions decrease with increasing concentration of the chloride, nitrate, perchlorate and sulphate ions. This may be explained on the basis of the stability constants of the complexes with those metal ions. SO42- may form strong complexes with $\mathrm{Fe} 3+, \mathrm{Ni2}+, \mathrm{Cu} 2+$ ions while $\mathrm{NO} 3-, \mathrm{Cl}-$ and $\mathrm{ClO} 4-$ may form weak complexes therefore increases uptake by increasing concentration. While SO42-, NO3-, Cl- and ClO4- form rather strong complex with $\mathrm{Co} 2+$, $\mathrm{Zn} 2+, \mathrm{Cd} 2+$ and $\mathrm{Pb} 2+$ chelates, therefore decreased uptake by increasing concentration. This type of trend has also been observed by other investigators in this field [8]. II. Rate of uptake of metal ions as a function of time The rate of metal adsorption was determined to find out the shortest period of time where we find as close as equilibrium condition. The rate refers to the change in the concentration of the metal ions in the aqueous solution which is in contact 
with the given polymer. The result shows that the time taken for the uptake of the different metal ions at a given stage depends on the nature of metal ion under given conditions. It is found that Fe (II) ions require about $3 \mathrm{hrs}$ for the establishment of the equilibrium, where as $\mathrm{Cu}$ (II), Ni (II), Co (II) and $\mathrm{Zn}$ (II) requires $5 \mathrm{hrs}$ and $\mathrm{Cd} 2+$ and $\mathrm{Pb} 2+$ require $6 \mathrm{hrs}$ for the establishment of the equilibrium. Thus the rate of metal ions uptake follows the order $\mathrm{Fe}$ (III) $>\mathrm{Cu}$ (II) $\approx \mathrm{Ni}(\mathrm{II})>\mathrm{CO}(\mathrm{II}) \approx \mathrm{Zn}$ (II) $>\mathrm{Cd}$ (II) $\approx \mathrm{Pb}$ (II) for all four $\mathrm{p}$-CDF terpolymer resins. The sequence of percentage of the amount of metal ion taken up at different time increases as the molar ratio of the terpolymer increases, p-CDF-I $<$ p-CDF-II $<$ p-CDF-III < p-CDF-IV. This sequence may be due to the more and more introduction of aromatic rings, $-\mathrm{OH}$ and $-\mathrm{CH} 3$ groups, in repeat unit of polymer chain. All the results are found to be in good agreement with earlier co-workers $[12,13]$. III. Distribution ratio of metal ions at different $\mathrm{pH}$ The effect of $\mathrm{pH}$ on the amount of metal ions distributed between two phases can be explained.

The data on the distribution ratio as a function of $\mathrm{pH}$ indicates that the relative amount of metal ion taken up by the $\mathrm{p}-\mathrm{CDF}$ terpolymer increases with increasing $\mathrm{pH}$ of the medium. The magnitude of increase however, is different for different metal cations. The $\mathrm{p}$-CDF terpolymer resin take up Fe (III) ion more selectively at lower $\mathrm{pH}$ of 1.5 to 3 , than any other metal ions under study. The order of distribution ratio of metal ions measured in $\mathrm{pH}$ range 1.5 to 3 is found, to be highest and in $\mathrm{pH}$ range of 3 to 6 the order is found to be $\mathrm{Cu}(\mathrm{II})>\mathrm{Ni}(\mathrm{II})>$ $\mathrm{Co}(\mathrm{II}) \approx \mathrm{Zn}(\mathrm{II})>\mathrm{Cd}(\mathrm{II})>\mathrm{Pb}$ (II). Thus the results of such type of study are helpful in selecting the optimum $\mathrm{pH}$ for a selective uptake of a particular metal cation from a mixture of different metal ions. For example the result suggests the optimum $\mathrm{pH} 6.0$ for separation of $\mathrm{Co}(\mathrm{II})$ and $\mathrm{Ni}(\mathrm{II})$ with distribution ratio "D" are 360.5 and 720.8 respectively using p-CDF terpolymer resin as ion-exchangers. For the separation of $\mathrm{Cu}$ (II) and $\mathrm{Fe}$ (II) the optimum $\mathrm{pH}$ is 3 , at which the distribution ratio "D" for $\mathrm{Cu}$ (II) is 42.9 and for Fe (III) is 421.6. The sequence of distribution ratios of four $\mathrm{p}-\mathrm{CDF}$ terpolymer resin is found to be $\mathrm{p}-\mathrm{CDF}-\mathrm{I}<="$ " td="" style="box-sizing: border-box;"> 


\section{Conclusion:}

The results of this type of study are helpful in selecting the optima $\mathrm{pH}$ for a selective uptake of a metal ion from a mixture of different ion. the ion-exchange capacity has been found to be 3.41 mili mol.g-1, which indicates that the $\mathrm{p}$ $\mathrm{CDF}$ terpolymer resin is better ion-exchanger for certain metal ion then some phenolic and polystyrene commercial ion-exchanger.

\section{Reference:}

Atia A. A., Donia A. M. and Flwakccl K. Z., Selective separation of mercury (II) using a synthetic resin containing amine and mercaptan as chelating groups, React Fund Polym, 65( 1), 267-275, (2005).

Boto B. A. and Pawlowski L., Waste Water Treatment by Ion Exchange, Chapman \& Hill. New York, (1987).

Katkamwar S.S., Zade A.B. and Rahangdalc, Gurnule W.B., Terpolymer resin. Ill ; Synthesis, characterization of p-Cresol - dithiooxamide -f ormaldehyde terpolymer resins, j. Appl. Polym.Sci 113(1), 3330-3335, (2009).

Nabi S, Alim A, Islam A, Amjad M, J Appl Polym Sci, 18, 2463-2467, (2005).

Nada M.A., Yousset A.M., Abdel-Nour K.N., Pigments and resin technol., 26(1), 17-23 (1997).

Orazzhanova L. K., Yashkarova M. G., Bimendina F. A. and Kudaibcrgenov S. D., Binary and ternary polymer- strontium complexes and the capture of radioactive strontium-90 from the polluted soil of the Semipalatinsk nuclear test site, J. Appl. Polym. Sci., 87( 1), 759-764, (2003).

Prabhakaran D., Subramanian M.S, Talanta, 59,1227-1236, (2003).

Ripper K., U.S. Patent, 1, 687, 312 (1928), 1, 763, 456 (1930), 2056, 142 (1936). 
Sellers T. Jr. Plywood and Adhesive Technology, Marcel Dekker, New York, 271-514 (1985).

Shah B.A., Shah A.V., Shah P. M., E. J. Chem., 5, 291-301 (2008).

Sherrington D. C. and Hoge P., Synthises and separations using functional polymers, John Wiley, Chichester,' (1988).

Silverstein R. M. and Webster F. X., Spectrometric identification of organic compounds, John Wiley and Sons, New York, (1998).

Singru R. N., Zade A. B. and Gurunule W.B., Synthesis, characterization, and thermal degradation studies of copolymer resin from p-cresol, melamine and formaldehyde, J. Appl. Polym. Sci., 109(1), 859-868, (2008)

Szabadka O., Varga F. and Nagy F.. Determination of protonation and metal complex stability constants for a chelating monomer and its immobilized in polymer resin, Talanta, 59(1), 1081-1088, (2003)

Tarase M. V., Zade A. B., Gurnule W. B. and Resin I., Synthesis, characterization and ion exchange properties of terpolymer resins derived from 2,4- dihydroxypropiophenone-biurct and formaldehyde, J. Appl. Polym. Sci., 108(1), 738-746, (2008).
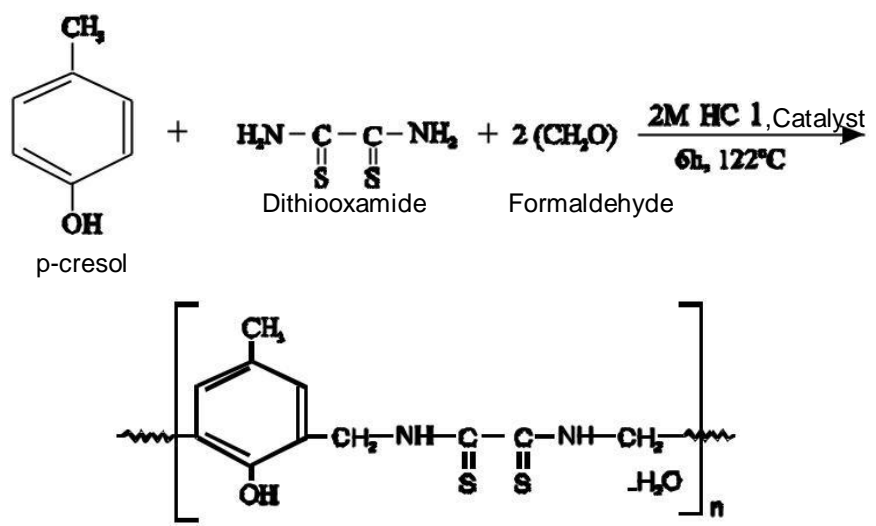

p-CDF Terpolymer

Fig. 1 Reaction and Suggested Structure of Representative p-CDF -I Terpolymer Resin 
Table 1: Elemental Analysis Data, Molecular weight Determination and Viscometric data of $\mathrm{p}-\mathrm{CDF}$ Terpolymer Resins

\begin{tabular}{|c|c|c|c|c|c|c|}
\hline $\begin{array}{c}\text { Terpolymer } \\
\text { Resins }\end{array}$ & $\begin{array}{c}\% \text { of C } \\
\text { observed } \\
\text { (Cal.) }\end{array}$ & $\begin{array}{c}\% \text { of } \mathbf{H} \\
\text { observed } \\
\text { (Cal.) }\end{array}$ & $\begin{array}{c}\% \text { of } \mathrm{N} \\
\text { observed } \\
\text { (Cal.) }\end{array}$ & $\begin{array}{c}\% \text { of } \mathrm{S} \\
\text { observed } \\
\text { (Cal.) }\end{array}$ & $\begin{array}{c}\text { Molecular } \\
\text { weight }\end{array}$ & $\begin{array}{c}\text { Intrinisic } \\
\text { viscosity }[\square]\end{array}$ \\
\hline p-CDF -I & $\begin{array}{c}48.17 \\
(48.78)\end{array}$ & $\begin{array}{c}4.94 \\
(5.17)\end{array}$ & $\begin{array}{c}10.86 \\
(10.34)\end{array}$ & $\begin{array}{c}19.9 \\
(20.4)\end{array}$ & 3901 & 0.6281 \\
\hline p-CDF -II & $\begin{array}{c}57.12 \\
(57.96)\end{array}$ & $\begin{array}{c}5.94 \\
(5.78)\end{array}$ & $\begin{array}{c}6.15 \\
(6.92)\end{array}$ & $\begin{array}{c}17.6 \\
(17.9)\end{array}$ & 6335 & 0.7134 \\
\hline p-CDF -III & $\begin{array}{c}62.74 \\
(63.12)\end{array}$ & $\begin{array}{c}4.97 \\
(5.08)\end{array}$ & $\begin{array}{c}4.86 \\
(5.39)\end{array}$ & $\begin{array}{c}18.2 \\
(18.5)\end{array}$ & 7998 & 0.8409 \\
\hline p-CDF -IV & $\begin{array}{c}66.58 \\
(66.47)\end{array}$ & $\begin{array}{c}6.76 \\
(6.03)\end{array}$ & $\begin{array}{c}3.97 \\
(4.39)\end{array}$ & $\begin{array}{c}19.7 \\
(19.8)\end{array}$ & 13728 & 0.9256 \\
\hline
\end{tabular}

